\title{
The influence of self-stretch based on post- isometric relaxation, static stretch combined with stabilization exercises and stabilization exercises only on hamstring, one-joint and two-joints hip flexors flexibility and finger-to-floor test results
}

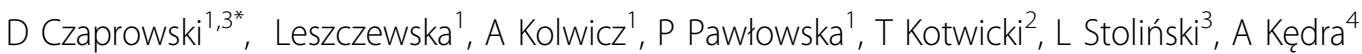

From 9th International Conference on Conservative Management of Spinal Deformities - SOSORT 2012

Annual Meeting

Milan, Italy. 10-12 May 2012

\section{Background}

Stretching techniques are commonly used in clinical practice to increase flexibility of muscles in children with idiopathic scoliosis, as well as with faults of body posture. The proper flexibility of muscles is important in prevention of postural imbalance, maintaining of full range of motion, or in decrease of risk of back pain.

\begin{abstract}
Aim
Prospective randomized single-blinded evaluation of changes of hamstring, one-joint and two-joint hip flexors flexibility in children under the 6-week therapeutic programme consisting of one physiotherapy session per week and daily home exercises.
\end{abstract}

\section{Methods}

94 children (46 boys and 48 girls) aged 10-13 years $(11.5 \pm 0.5)$, were randomly divided into 3 groups. Each group underwent a 6-week therapeutic programme aiming to correct muscles flexibility. The first group-GI (31 children) realized the programme of post isometric muscle relaxation (PIR), the second one-GII (31 children) performed static stretching with stabilization exercises, the third group-GIII (32 children) realized only stabilization exercises. The shortening of hamstring, one-joint and two-joint hip flexors was assessed

'Department of Physiotherapy, Józef Rusiecki University College in Olsztyn, Olsztyn, Poland

Full list of author information is available at the end of the article clinically according to Kendall. The straight leg raise (SLR test) angle and the popliteal angle were measured for hamstrings, the angle in sagittal plane in hip for one-joint and the knee flexion was measured for twojoint hip flexors. Fingertips-to-floor distance (FTF test) in trunk flexion was also noted. The examination was conducted twice - before therapy and a week after its completion, by the blinded observers.

\section{Results}

No difference in the amount of correction of muscle flexibility among the three groups was found for hamstrings $(\mathrm{p}=0.14)$, one-joint $(\mathrm{p}=0.38)$ and two-joint hip flexors $(\mathrm{p}=0.28)$ as well as for FTF test $(\mathrm{p}=0.15)$. Significant correction of all muscle flexibility and FTF test $(\mathrm{p}<0.05)$ was observed in GI and GII groups. In GIII significant improvement $(\mathrm{p}<0.05)$ in SLR test and flexibility of one-joint hip flexors was obtained.

\section{Conclusions}

Postisometric muscle relaxation, static stretching with stabilization exercises, as well as only stabilization training had similar influence on the improvement of muscle flexibility. Body suppleness, as assessed by fingertips-tofloor distance, was improved only after used techniques included stretching exercises (PIR, static stretching), but there were no differences between all three groups regarding changes in FTF test. Regardless of the stretching methods, a 6-week physiotherapeutic procedure 
resulted in increased flexibility of the muscles of the pelvic girdle.

\section{Author details}

${ }^{1}$ Department of Physiotherapy, Józef Rusiecki University College in Olsztyn, Olsztyn, Poland. 'Department of Pediatric Orthopedics and Traumatology, University of Medical Sciences in Poznań, Poland. ${ }^{3}$ Rehasport Clinic, Poznań, Poland. ${ }^{4}$ Faculty of Physical Education and Sport in Biala Podlaska, Józef

Piłsudski University of Physical Education in Warsaw, Poland.

Published: 3 June 2013

\section{References}

1. G F: Muscle energy technique: research and efficacy. Edinburgh: Churchill Livingston;Chaitow L , 3 2006:.

2. Shrier I: Does stretching improve performance? A systematic and critical review of the literature. Clin J Sport Med 2004, 14(5):267-273.

3. Sjolie AN: Low-back pain in adolescents is associated with poor hip mobility and high body mass index. Scand J Med Sci Sports 2004, 14(3):168-175.

doi:10.1186/1748-7161-8-S1-P1

Cite this article as: Czaprowski et al:: The influence of self-stretch based on post-isometric relaxation, static stretch combined with stabilization exercises and stabilization exercises only on hamstring, one-joint and two-joints hip flexors flexibility and finger-to-floor test results. Scoliosis 2013 8(Suppl 1):P1.

\section{Submit your next manuscript to BioMed Central} and take full advantage of:

- Convenient online submission

- Thorough peer review

- No space constraints or color figure charges

- Immediate publication on acceptance

- Inclusion in PubMed, CAS, Scopus and Google Scholar

- Research which is freely available for redistribution

Submit your manuscript at www.biomedcentral.com/submit
C Biomed Central 